\title{
Changes in Country Names
}

\author{
Colonial Name \\ Basutoland \\ Belgian Congo \\ British Togoland \\ Cameroons (formerly Kamerun) \\ Central African Federation \\ Dahomey \\ French Guinea \\ French Sudan \\ French Togo \\ Gold Coast \\ Middle Congo \\ Northern Rhodesia \\ Nyasaland \\ Portuguese Guinea \\ Ruanda \\ Somaliland
}

Southern Rhodesia

South-West Africa

Spanish Guinea

Tanganyika

Ubangi-Chari

Union of South Africa

Upper Volta

Urundi

Zanzibar
Independence Name and Date

Lesotho, 1966

Rep. of Congo; Zaire since 1971

merged with Ghana at

independence, 1957

Cameroon, 1961

dissolved in 1963 into Nyasaland, Northern and Southern Rhodesia Rep. of Dahomey, 1960; Benin since 1975

Guinea, 1958

Mali, 1960

Togo, 1960

Ghana, 1957

The Congo, 1960

Zambia, 1964

Malawi, 1964

Guinea-Bissau, 1974

Rwanda, 1962

Somalia (formed from British and Italian Somaliland), 1960

Zimbabwe, 1980; (previously

Rhodesia, 1965-1979)

Namibia, 1990

Equatorial Guinea, 1968

Rep. of Tanganyika, 1961; united with Rep. of Zanzibar to form Tanzania, 1964

Central African Republic, 1960

Rep. of South Africa, 1961

Rep. of Upper Volta, 1960;

Burkina Faso since 1984

Burundi, 1962

Rep. of Zanzibar, 1963; united with Tanganyika to form Tanzania, 1964 
